\title{
Agnathia-holoprosencephaly-situs inversus syndrome
}

INSERM

\section{Source}

INSERM. (1999). Orphanet: an online rare disease and orphan drug data base. Agnathiaholoprosencephaly-situs inversus syndrome. ORPHA:990

Agnathia-holoprosencephaly-situs inversus syndrome is an extremely rare and fatal association syndrome, characterized by absence of the mandible, cerebral malformations with facial anomalies related to a defect in cleavage in the embryonic brain (e.g. synophthalmia, malformed and low-set ears fused in midline (otocephaly), agenesis of the olfactory bulbs, microstomia, hypoglossia/aglossia) and situs inversus partialis or totalis. 